\title{
Adipose Tissue Dendritic Cells: Critical Regulators of Obesity-Induced Inflammation and Insulin Resistance
}

\author{
Shindy Soedono ${ }^{1}$ and Kae Won Cho ${ }^{1,2, *(D)}$ \\ 1 Department of Integrated Biomedical Science, Soonchunhyang University, Cheonan 31151, Korea; \\ shindysoedono@sch.ac.kr \\ 2 Soonchunhyang Institute of Medi-Bio Science (SIMS), Soonchunhyang University, Cheonan 31151, Korea \\ * Correspondence: kwcho@sch.ac.kr; Tel.: +82-41-413-5028
}

Citation: Soedono, S.; Cho, K.W Adipose Tissue Dendritic Cells: Critical Regulators of Obesity-Induced Inflammation and Insulin Resistance. Int. J. Mol. Sci. 2021, 22, 8666. https://doi.org/ $10.3390 /$ ijms 22168666

Academic Editors: Melania Manco and Amalia Gastaldelli

Received: 18 May 2021

Accepted: 9 August 2021

Published: 12 August 2021

Publisher's Note: MDPI stays neutral with regard to jurisdictional claims in published maps and institutional affiliations.

Copyright: (c) 2021 by the authors. Licensee MDPI, Basel, Switzerland. This article is an open access article distributed under the terms and conditions of the Creative Commons Attribution (CC BY) license (https:// creativecommons.org/licenses/by/ $4.0 /)$.

\begin{abstract}
Chronic inflammation of the adipose tissue (AT) is a critical component of obesity-induced insulin resistance and type 2 diabetes. Adipose tissue immune cells, including AT macrophages (ATMs), AT dendritic cells (ATDCs), and T cells, are dynamically regulated by obesity and participate in obesity-induced inflammation. Among AT resident immune cells, ATDCs are master immune regulators and engage in crosstalk with various immune cells to initiate and regulate immune responses. However, due to confounding markers and lack of animal models, their exact role and contribution to the initiation and maintenance of AT inflammation and insulin resistance have not been clearly elucidated. This paper reviews the current understanding of ATDCs and their role in obesity-induced AT inflammation. We also provide the potential mechanisms by which ATDCs regulate AT inflammation and insulin resistance in obesity. Finally, this review offers perspectives on ways to better dissect the distinct functions and contributions of ATDCs to obesity.
\end{abstract}

Keywords: obesity; adipose tissue; dendritic cells; insulin resistance; inflammation; antigen presentation

\section{Introduction}

Obesity is a chronic low-grade inflammatory state, essential in the pathogenesis of metabolic disorders, including insulin resistance and type 2 diabetes [1]. The adipose tissue (AT) is the primary and first organ affected by inflammation and sustains obesityinduced inflammation [2]. Various immune cell types, including macrophages, dendritic cells (DCs), and T and B cells, have been identified in the AT and implicated as key players in obesity-associated immune responses. Numerous studies demonstrated that the composition of both myeloid and lymphoid cell profiles dynamically changes, and their inflammatory output shifts with increased adiposity $[3,4]$. In addition to the specific immune cell population changes, crosstalk between innate and adaptive cells is crucial in the regulation of inflammation. Therefore, understanding AT inflammation through the integration of innate and adaptive immune cells will provide a new understanding of the pathophysiology of diabetes and related metabolic syndromes.

Dendritic cells are the latest discovered hematopoietic stem cell lineage and are classified as part of the innate immune system. Their main role is to act as antigenpresenting cells (APCs) and as such have the capacity of recognizing pathogens, become activated through antigen processing, migrating, and the presenting of the antigen to naïve $T$ cells, as well as the secreting of cytokines [5-7]. Since DCs control innate and adaptive immunity, therefore orchestrating immunity, they have been considered as key regulators in obesity-induced inflammation [8-11]. However, AT macrophages (ATMs) also express CD11c, a DC marker, which makes it difficult to distinguish AT dendritic cells (ATDCs) from ATMs. Moreover, not only DCs, but macrophages can also function as APCs that respond to local environmental cues, adapting their morphological and functional phenotype to these signals. They regulate the types of adaptive immune response initiated 
by obesity. Thus, the understanding of ATDC's specific function has been limited by confounding markers.

Several research groups, including us, have explored new markers to delineate ATDCs. Our group previously reported that CD64 is exclusively expressed in ATMs, and it can be used to distinguish ATMs from ATDCs in both obese human and mouse [12]. Using CD64 and CD11c, we identified ATDCs as an independent contributor to AT inflammation and insulin resistance in obesity [13]. Recently, several studies revealed new DC functions and expanded the understanding of ATDCs in obesity. In this review, we summarize the characteristics of DCs, especially in the AT. Furthermore, this review describes the role of ATDCs in both lean and obese states. Finally, we provide the potential regulatory mechanisms of ATDCs as the key players in obesity-induced inflammation and insulin resistance.

\section{Phenotypic Characteristics of Adipose Tissue Dendritic Cells}

\subsection{Dendritic Cells: Subsets and Properties}

Dendritic cells are professional APCs, defined by a high expression of integrin alpha X (ITGAX) or CD11c as well as major histocompatibility complex-II (MHC-II). Under steady state, there are two main DC lineages in blood and tissues, both originating from the bone marrow hematopoietic stem and progenitor cells (HSPCs): the comparatively rare plasmacytoid DC (pDC), and the more common conventional DC (cDC) [14]. While pDCs are major regulators in antiviral $\mathrm{CD}^{+} \mathrm{T}$ cell activation [15], pDCs show lowerlevel expression of genes such as CD11c and MHC-II and poor ability to stimulate T cells $[16,17]$. Thus, in tissues, $\mathrm{CDC}$ is the major resident DC capable of antigen presentation (AP), as well as cytokine and chemokine production for pathogen elimination [14,18]. Under inflammatory conditions, monocyte-derived DCs (moDCs) arise from monocyte recruitment with the same phenotype as cDCs [19].

Conventional DCs can be further categorized into two subsets based on different lin-

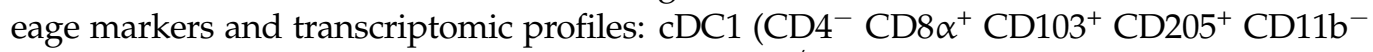
CLEC9A $\left.^{+} \mathrm{XCR}^{+}{ }^{+} \mathrm{CD} 24^{+}\right)[16,19-22]$ and $\mathrm{CDC} 2\left(\mathrm{CD} 4^{+/-} \mathrm{CD} 8 \alpha^{-} \mathrm{CD}^{-005^{-} \mathrm{CD} 11 \mathrm{~b}^{+} \text {CLEC4A4 }}{ }^{+}\right.$ $\mathrm{CD}^{+} 4^{+}$[23-25]. cDC1s have a higher expression of transcription factors interferon regulatory 8 (IRF8) and BATF3, while cDC2s are regulated by interferon regulatory 4 (IRF4) [13,16,24]. cDC1 specialize in cross-presentation to $\mathrm{CD} 8^{+} \mathrm{T}$ cells and $\mathrm{CDC} 2$ activate $\mathrm{CD} 4^{+} \mathrm{T}$ cell differentiation. Homolog subsets and function in mouse DCs can be found in human DCs with different surface marker, which are categorized into three populations: $\mathrm{CDC} 2\left(\mathrm{CD} 1 \mathrm{c}^{+}\right)$, $\mathrm{cDC} 1\left(\mathrm{CD} 141^{+}\right)$, and $\mathrm{pDC}\left(\mathrm{CD} 303^{+}\right)$. In addition, human moDCs expressed CD14 ${ }^{+}$, presumed to be the precursor of inflammatory DCs [26]. Despite marker differences, functional properties and distribution of each DC subset among species are similar. In steady state, the population of $\mathrm{cDC} 1$ is lower than that of $\mathrm{cDC} 2$. Further, visualization of $\mathrm{cDC}$ subsets reveals differential localization in lymphoid tissues. In the lymph node (LN) and the spleen, $\mathrm{cDC} 1 \mathrm{~s}$ are located in the $\mathrm{T}$ cell zone. On the contrary, $\mathrm{cDC} 2 \mathrm{~s}$ are more peripherally distributed and express various receptors to respond to antigens [23,24,27-29]. Whether the localization of $\mathrm{CDC}$ subsets in peripheral tissues, including the AT, would be different remains elusive.

\subsection{ATDC Characteristics, Quantitation, and Subsets in Lean and Obese States}

The identification and characterization of ATDCs have been extensively studied in many experimental mouse models using a distinct set of cell-surface markers, including CD11c. Bertola et al. [30] demonstrated that CD11 $\mathrm{c}^{\text {high }} \mathrm{B} 220^{-}$cells are a heterogeneous group of DCs in the AT that contain several distinct subpopulations, including $\mathrm{CD} 11 \mathrm{c}^{+} \mathrm{F} 4 / 80^{\text {neg }}$ and $\mathrm{CD} 11 \mathrm{c}^{+} \mathrm{F} 4 / 80^{\mathrm{low}}$. At the same time, another group reported that substantial proportions of $\mathrm{CD}_{11 \mathrm{c}^{+}}$cells in AT are DCs, which was confirmed in a DC deficient model, $\mathrm{Flt3l}^{-/-}$mice [31]. The existence of ATDCs was also supported by the observation of some $\mathrm{CD} 11 \mathrm{c}^{+}$cells displaying a rough surface with multiple pseudopodia, identical to the typical DC morphology [30,32]. Moreover, these cells can induce T cell polarization from 
naïve T cells $[12,30,33]$, which confirms the existence of functional ATDCs in the lean state to maintain a tolerogenic state.

Similar to other peripheral tissue DCs, ATDCs can be defined by a high expression of CD11c and MHC-II. Around $80-90 \%$ of ATDCs express CD11b, indicating that CDC2 is the predominant ATDC subset. Co-stimulatory molecules, such as CD40, CD80, and CD86, are also expressed by ATDCs. However, these surface antigens are confounding markers to define pure ATDCs, since ATMs, the most abundant myeloid cells, also express them to different extents depending on inflammatory status [30,34,35]. Previously, we reported that separation of ATDCs from ATMs can be achieved by using CD64 and MerTK, as ATDCs

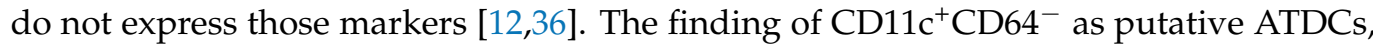
independent of ATMs contamination, makes it possible to distinguish ATDCs from ATMs in obesity. In addition to those markers, the transcription factor ZBTB46 has been known to be useful to define $\mathrm{cDC}$, but not $\mathrm{pDCs}$, macrophages, or monocyte-derived cells [37]. Consistently, gene expression array data showed that Zbtb46 is exclusively expressed in ATDCs, both in lean and obese AT [12]. Visualization of $\mathrm{CDC}$ using a reporter mouse (Zbtb46-GFP) showed that only $40 \%$ of cells among CD11c ${ }^{+}$MHC-II ${ }^{+}$cells are $\mathrm{GFP}^{+} \mathrm{cDC}$ subsets in visceral adipose tissue (VAT), indicating the usefulness of ZBTB46 as a marker to delineate ATDC subset characteristics [38].

ATDCs have been recognized as a substantial proportion of infiltrating cells within the AT [39]. Accumulation of DC in subcutaneous AT (SAT) of obese human has been reported using marker $\mathrm{CD} 11 \mathrm{c}^{+} \mathrm{CD} 1 \mathrm{c}^{+}$, the increment of which was correlated with body mass index (BMI) [30]. In mouse studies, infiltrating ATDCs are associated with crown-like structures (CLS) in the AT of high fat diet (HFD)-fed mice [12] and appear to accumulate with moderate HFD exposure [12,31]. In VAT, ATDCs have been shown to significantly increase after diet-induced obesity (DIO), from $<5 \%$ in normal diet (ND) to around $10 \%$ after 8 weeks of HFD [12,40]. Based on flow cytometry of obese ATDCs, this increasing population is mainly coming from $\mathrm{CD}_{11 b^{+}}$subsets or $\mathrm{CDC} 2 \mathrm{~s}$ [12]. Sharing markers with CDCs, moDC recruitment is increased in obese AT [41,42]. It is also reported that obesity increases the $\mathrm{pDC}\left(\mathrm{CD} 11 \mathrm{c}^{+} \mathrm{PDCA} 1^{+}\right.$cells) population in VAT [31]. Collectively, despite the differences among ATDC subsets, all subsets in obese VAT were increased compared to lean VAT [12,31]. Interestingly, recent single cell analysis revealed the existence of three different ATDC populations in obese VAT: MHC-I presenting DCs, MHC-II presenting DCs, and replicating DCs or moDCs, whose proportions were changed by obesity [43]. Advances in single cell multiomics will provide a more comprehensive understanding of ATDCs in obesity.

Immature and mature DCs have different phenotypic and functional characteristics [32]. During maturation, DCs go through phenotypic alterations, such as induction of genes related to AP. In parallel with inflammation, obesity upregulates the surface presentation of MHC molecules in ATDC, indicating a higher AP. Expression of co-stimulatory molecules such as CD40, CD80, and CD86 was also enhanced in obese ATDCs [12,30,44]. A wide array of cytokines produced by DCs are also controlled by obesity. Gene expression data of sorted ATDCs demonstrated that obese ATDCs show a higher expression of IL-12, IL-18, and IL-6, indicating that obesity induces ATDC activation and maturation [12,30]. These alterations, including AP properties and cytokine production, would induce the different functional properties of ATDCs in obesity.

\subsection{Mechanism of Obesity-Induced ATDC Expansion}

The accumulation of immune cells in peripheral tissues is tightly regulated by the local proliferation, migration from blood, or both. In early stages of obesity, ATDC proliferation, as detected by the Ki67 marker, is induced in both VAT and SAT as early as three days after HFD initiation, and the number of ATDCs significantly increases after seven days of HFD, both in VAT and SAT. Furthermore, Ki67 ${ }^{+}$ATDCs were found to keep increasing until 14 days of HFD in SAT. In contrast to SAT, ATDC proliferation is not positively correlated with the frequency of ATDCs in VAT [40]. Increased infiltration rates of ATDCs to VAT 
is in accordance with chronic inflammation progression, where it keeps increasing after 4 weeks HFD and goes up further at least until 8 weeks of HFD [12,40]. However, the ATDC population percentage is reduced after 16 weeks of HFD, specifically in VAT but not in SAT [12]. These results suggest that mechanisms responsible for the obesity-induced ATDC expansion may be AT depot-specific. It still remains to be investigated whether ATDCs in VAT and SAT have different features, functions, and/or specific ones during obesity progression.

Blood contains DC precursors and differentiated DC subsets as well as pluripotent HSPCs, which are able to differentiate into different DC subsets and circulating monocytes. Circulating DCs and their precursors exit the blood in response to tissue-specific recruitment signals, like a response to inflammation or as part of tissue-resident DC turnover [45]. During obesity, ATDC migration tracking has been studied using $\mathrm{Ccr} 7^{-/-}$ mice, as ATDC migration is specifically dependent on CCR7 but independent of CCR2, whereas monocyte-derived ATMs are dependent on CCR2. This study also confirmed parallel mechanism of DC migration in human, which was CCR7-dependent [12]. Although chemokine-chemokine receptor pathways such as CCR2-CCL2, CCR5-CCL5, and CCR6-CCL20 are important to gain access to non-lymphoid peripheral tissues [45], there are limited studies identifying specific chemokines regulating ATDC accumulation and arrest in tissues. It remains to be investigated how excess nutrition in early obesity triggers the increase of ATDC populations and whether it is caused by ATDC's maturation and migration signal itself or other cell-derived factors.

\section{Functional Characteristics of ATDCs}

\subsection{Body Weight Regulator}

Inflammation regulates energy metabolism and is directly involved in the pathogenesis of obesity-induced metabolic disorders. As a contributor to inflammation, DCs are emerging as an important regulator of energy homeostasis as well. Apparently, the loss of DCs in a mouse model (Flt3l $l^{-/-}$mice) prevents HFD-induced weight gain [31]. FMS-like tyrosine kinase 3 (Flt3) is expressed by early hematopoietic progenitor cells, and without its ligand (Flt3L), there is a defect in migration and expansion from bone marrow to the peripheral lymphoid tissue [46], causing DC ablation in peripheral tissues. Interestingly, DC depletion in $\mathrm{Flt3l}^{-/-}$mice resulted in resistance to obesity and normal body weight gain. Moreover, $\mathrm{Flt}_{3 \mathrm{I}^{-/}}$mice showed increased heat production, indicating increased metabolic rate as a potential mechanism to prevent body weight gain [31].

Another study to characterize DC function was performed in the $C s f 2^{-1-}$ mouse model, another whole-body DC depletion model. Granulocyte-Macrophage Colony Stimulating Factor (GM-CSF) is encoded by Csf2 and is essential for moDC generation, DC maturation, and DC survival, to become fully functional as APCs [47]. In Csf2 ${ }^{-/-}$mice, reduction of DCs $\left(\mathrm{CD} 45^{+} \mathrm{CD} 11 \mathrm{~b}^{+} \mathrm{CD} 11 \mathrm{c}^{+} \mathrm{MHC}-\mathrm{II}^{+} \mathrm{F} 4 / 80^{\text {low }}\right.$ cells) is followed by lower body weight compared to $C s f 2^{+/+}$mice [47-49]. $C \mathrm{cr} 7^{-/-}$mice also lack peripheral DCs, as lacking CCR7 expression lowers the ability of DCs to migrate in response to their activation. Interestingly, $\mathrm{Ccr}^{-1-}$ mice are protected against body weight gain under an HFD challenge, with enhanced energy expenditure and Ucp1 activation in VAT and brown AT (BAT) [50].

Overall, these studies demonstrate the body weight alteration when most of DCs disappear. It would be interesting whether the effect of global depletion of DCs in the various knockout models is a direct or indirect effect on the reduced body weight. Another interesting question is whether antigen-induced activation might be involved in ATDC's function. However, the results from the above whole-body DC depletion models do not exclude the possibility of the developmental defects as well as the interference of other cells. In Flt $3 l^{-/}$mice, the development of other cells regulated by DCs was also altered, including natural killer (NK) cells, regulatory T cells (Tregs), and B cells [51]. Similarly, in Csf2 ${ }^{-/-}$mice, GM-CSF regulates the development of granulocytes as well as monocytes [48], whereas in $\mathrm{Ccr}^{-/-}$mice, CCR7 is also expressed by certain T and B cells [50]. Thus, further studies are required to clarify if DC is the real regulator of body weight and if yes, how DC 
directly or indirectly affects body weight, whether through DC's derived factor or DC's AP function.

\subsection{Regulator of Adipose Tissue Homeostasis in the Lean State}

In steady state, DCs play an important role in tissue homeostasis by maintaining the peripheral tolerance. Tolerogenic function of ATDCs in the lean state may be related with immature phenotype, which is characterized by a lower extent of maturation marker expression such as CD80 and CD86 [52]. It is also known that tolerogenic functions of DCs can be directed and enhanced by the targeted delivery of defined antigen. The functional characteristics of ATDCs in the lean state could be partly observed in the inducible CD11cDTR mouse model, which expressed human diphtheria toxin receptor (DTR) under Cd11c promoter [53]. After diphtheria toxin (DT) administration in lean mice, depletion of CD11c $\mathrm{c}^{+}$ cells did not disrupt $\mathrm{CD} 4^{+} \mathrm{T}$ cell numbers and proliferation [12,54], suggesting steady-state $\mathrm{CD}^{+} \mathrm{T}$ cell activation. A similar model using MHC-If ${ }^{\mathrm{fl} / \mathrm{fl}} \mathrm{CD} 11 \mathrm{c}-\mathrm{Cre}(\mathrm{M} 11 \mathrm{cKO})$ showed no differences in metabolic profiles in the lean state, even though MHC-II expression was depleted in $\mathrm{CD} 11 \mathrm{c}^{+}$cells [33]. This might be due to the heterogeneity of ATDC populations, containing several distinct subpopulations which could replace each other's functions.

ATDCs' tolerogenic function is properly maintained by intercommunication with adipocytes. Macdougall et al. found that each $\mathrm{cDC}$ subset contributes to a tolerogenic environment by different mechanisms. The $\mathrm{CDC} 1$ subset has an active Wnt/ $\beta$-catenin pathway, whereas the $\mathrm{CDC} 2$ subset has an active $\operatorname{PPAR} \gamma$ pathway that negatively regulates inflammatory gene expression through transrepression of NF- $\kappa \beta$ target genes. In the lean state, adipocyte-derived $\beta$-catenin would induce activation of the Wnt/ $\beta$-catenin signaling pathway in CDC1 and further induce anti-inflammatory cytokine IL-10 production. Separately, adipocyte-secreted dietary lipids could induce PPAR $\gamma$ signaling in $\mathrm{CDC} 2$, which would suppress its activation of inflammatory DC. Induction of both signaling pathways could suppress toll-like receptor-4 (TLR4)-induced inflammation in VAT; however, interestingly, cDC1 tolerogenic function deletion by $C t n n t b 1^{-/-}\left(C t n n b 1^{f l / f l}\right.$ zDC-Cre) and cDC2 by $P P A R \gamma^{-/-}\left(P P A R \gamma^{f l / f l} \mathrm{zDC}-\mathrm{Cre}\right)$ in ND-fed mice did not produce any differences in metabolic parameters [38].

A specific tolerogenic DC subset, called perf-DC, was characterized by Zangi et al. by its ability to secrete perforin. The perf-DC subset is derived from HSPCs (defined as $\mathrm{Lin}^{-} \mathrm{Sca}^{+} \mathrm{CKit}^{+}$) and contributes to $2-4 \%$ of CD11c $\mathrm{c}^{+} \mathrm{DC}$ within the secondary lymphoid organ (SLO), which further increases after GM-CSF administration. The unique perf-DC tolerogenic function was shown by the specific interaction between peptide-MHC and the T-cell receptor (TCR) of $\mathrm{CD}^{+} \mathrm{T}$ cells, which would activate toll-like receptor-7 (TLR7) and triggering receptor expressed on myeloid cells-1 (TREM-1) signaling in DC to induce perforin and granzyme A secretion, which could selectively kill CD8 ${ }^{+} \mathrm{T}$ cells [55]. Further, in mice with depletion of CD11 $\mathrm{c}^{+}$Perf $^{+}$DC (Itgax-DTA-Prf1 ${ }^{-/}{ }^{-}$) under steady state, longterm metabolic alterations similar to type 2 diabetes were produced. Even under ND, five months after depletion, it still resulted in increased body weight, body fat, leptin level, TNF $\alpha$ level, glucose intolerance, insulin resistance, adipocyte hypertrophy, and CLS formation [56]. Collectively, in the lean state, certain ATDC subsets would play important roles in AT homeostasis, by acting as a gatekeeper to control adaptive immunity as well as nurture an anti-inflammatory environment.

\subsection{Key Regulator of Adipose Tissue Inflammation in Obesity}

The functional characteristics of ATDCs in obesity have been established using various loss-of-function models. Whole-body DC depletion models such as the Flt $3 l^{-/-}$mice and $\mathrm{Csf2} 2^{-/-}$mice showed protection from obesity-induced insulin resistance, indicating the role of DCs in obesity-induced glucose homeostasis [31,48,49]. While Flt3l ${ }^{-/-}$mice are resistant to DIO [31], Csf2 ${ }^{-/}$mice exhibit insulin sensitivity despite increased adiposity in response to HFD [48,49]. These discrepancies imply diverse protective mechanisms of DC against obesity-induced glucose homeostasis. Another model to characterize DC 
function is the $C \mathrm{Cr} 7^{-/-}$mouse, which contains few peripheral DCs due to inhibition of ATDC chemotaxis [12]. Interestingly, $\mathrm{Ccr}^{-/-}$mice exposed to HFD did not suffer ATDC accumulation in VAT followed by protection to AT inflammation and insulin resistance, indicating the important participation of ATDC migration in early stages of obesity $[12,50]$. Improved metabolic profiles were accompanied by reduced CLS formation, lower $I l 6$, and higher Foxp3 expression in VAT [12]. Overall, these studies showed that DCs in the AT could be an important regulator of glucose homeostasis, related to AT homeostasis during obesity-induced inflammation.

To avoid any developmental defect and delineate the ATDC function in the obese state, an inducible DC ablation model has been considered. Exploration of CD11 $\mathrm{c}^{+}$cell function during obesity, including ATDC and CD11 ${ }^{+}$ATMs, has been observed in CD11c-DTR mice. Ablation of $\mathrm{CD}_{11 \mathrm{c}^{+}}$cells in obese mice lead to the improvement of obesity-induced inflammation and insulin resistance, accompanied by reduction of $\mathrm{T}$ cell activation, with higher proliferation of Tregs but not conventional T cells [57]. Another study with same model, showed that $\mathrm{CD} 11 \mathrm{c}^{+}$cell ablation results in the reduction of CLS formation with increased $I l 10$ and decreased Il6 and Mcp1 expression in VAT [54].These results indicate the crucial role of ATDCs to activate $\mathrm{CD} 4^{+} \mathrm{T}$ cells that contributes to AT inflammation in obesity.

ATDCs are heterogeneous groups composed of various subpopulations. Although it is known that the CD11 $\mathrm{c}^{+}$ATDC is the key player in obesity, the functions of the specific ATDC subset were recently identified. Macdougall et al. reported that deletion of tolerogenic function in each specific $\mathrm{CDC}$ subset, $\mathrm{cDC} 1$ and $\mathrm{cDC} 2$, using Ctnntb1-/mice and $P P A R \gamma^{-/-}$mice, respectively, resulted in worsened insulin resistance under 12 weeks HFD [38]. Perf-DC was identified as the distinct tolerogenic subset of ATDCs in obesity by using Itgax-DTA-Prf1 ${ }^{-/-}$chimera HFD mice, where CD11 $\mathrm{c}^{+}$Perf $^{+}$DC depletion exacerbates metabolic parameters such as body weight, VAT weight, liver weight, liver triglycerides, leptin level, insulin level, and also proinflammatory cytokine secretion, including IL-1 $\beta$ and TNF $\alpha$ [56]. Overall, these data implied that the tolerogenic function of certain DC subsets could be an important contributor in AT inflammation.

The AP function of ATDCs is considered the primary pathway that regulates obesityinduced inflammation. A number of studies showed that deletion of AP genes such as MHC-II, CD40L, and CD80/CD86 lead to marked changes in obesity-induced inflammation and insulin resistance [58-62]. However, since AP can also be performed by other APCs in addition to ATDCs [57], a direct and specific ATDC depletion model should be considered to elucidate the AP function of ATDCs in obesity. To this end, Lumeng groups developed MHC-If ${ }^{\mathrm{fl} / \mathrm{fl}}$ Itgax-Cre (M11cKO) and MHC-II ${ }^{\mathrm{fl} / \mathrm{fl}}$ Lysm-Cre (MMKO) mice as putative ATDC- and ATM-specific MHC-II knockout models [12,33]. Regarding the obesity-induced AT inflammation, both M11cKO mice and MMKO mice showed decreased $\mathrm{CD}^{+} \mathrm{T}$ cells. The reduction of TCR expression and lower frequency of effector/memory $\mathrm{CD}^{+} \mathrm{T}$ cells were also observed in M11cKO and MMKO mice, respectively. These results support the existence and the importance of APC function of ATDCs in obesity-induced AT inflammation.

Taken all together, the ATDC is a key player in obesity-induced inflammation and insulin resistance, where it potentially regulates body weight while preserving AT function and homeostasis, especially in obesity (Figure 1). However, the contribution of ATDCs is still not fully explored. The characterization of the AP function of specific ATDC subsets and the MHC-I presentation of ATDCs is also warranted. 


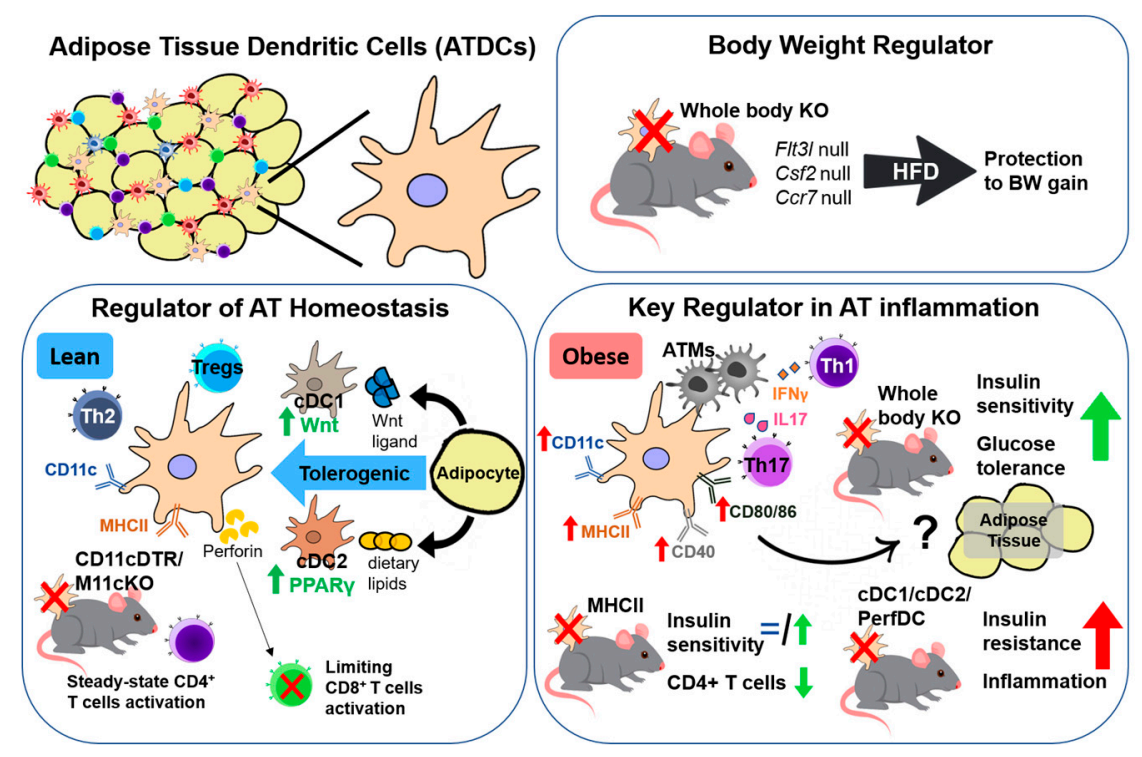

Figure 1. Functional characteristics of adipose tissue dendritic cells (ATDCs). In steady state, ATDCs have a tolerogenic function (green arrow) and together with adipocytes maintain adipose tissue (AT) homeostasis. Obesity challenges in the absence of dendritic cells (DCs) prevent body weight (BW) gain and become a key regulator in AT inflammation and insulin resistance (red arrow) by interacting with $\mathrm{T}$ cells and adipose tissue macrophages (ATMs).

\section{Mechanisms of ATDCs in Obesity-Induced Inflammation and Insulin Resistance}

As a controller of innate and adaptive immunity, DC participates in the inflammatory function through the crosstalk with other cells. The diversity of AT resident cells facilitates the crosstalk between ATDCs and other key players that potentially regulate AT inflammation. Herein, we will discuss the interaction between ATDCs and T cells, ATMs, and other non-immune cells in response to environmental cues that potentially regulate AT inflammation, such as obesity, as summarized in Figure 2.

\subsection{Regulator of Adipose Tissue Inflammation through T Cell Interaction}

$\mathrm{T}$ cells play an important role in obesity-induced inflammation, and their numbers will increase in VAT obese mice and humans compared to a lean phenotype [63,64]. Interestingly, $\mathrm{T}$ cell expansion happens at early stages of obesity, when ATDCs are increasing and before the infiltration of ATMs to VAT $[58,64,65]$. Since naïve $\mathrm{CD} 4^{+} \mathrm{T}$ cells are activated after interaction with DC and differentiate into specific subtypes [66], crosstalk between ATDCs and $\mathrm{T}$ cells is considered as the primary mechanism to regulate AT inflammation.

Among diverse subsets of $\mathrm{CD}^{+}$cells, activation of T helper 1 (Th1) and T helper 17 (Th17) subsets has been implicated in obesity-induced adipose inflammation. Th1 and Th17 activation has a correlation with obesity, where IFN $\gamma$ and IL-17 production are increased [30,57,58,67-73]. Consistent with the alteration of T cell subsets in obesity, obese ATDCs display higher capabilities to induce Th1 and Th17 activation seen in both human and mouse [30,52]. Moreover, ablation of AP function in DCs suppressed the obesityinduced $\mathrm{CD}^{+} \mathrm{T}$ cell increment in VAT [33]. These observations indicate that ATDCs mediate obesity-induced T cell activation. Furthermore, the IFN $\gamma$ produced by Th1 will further activate DCs' AP function to increase its MHC-II, in a feed-back loop, which would cause AT inflammation $[58,65,68,70]$. 


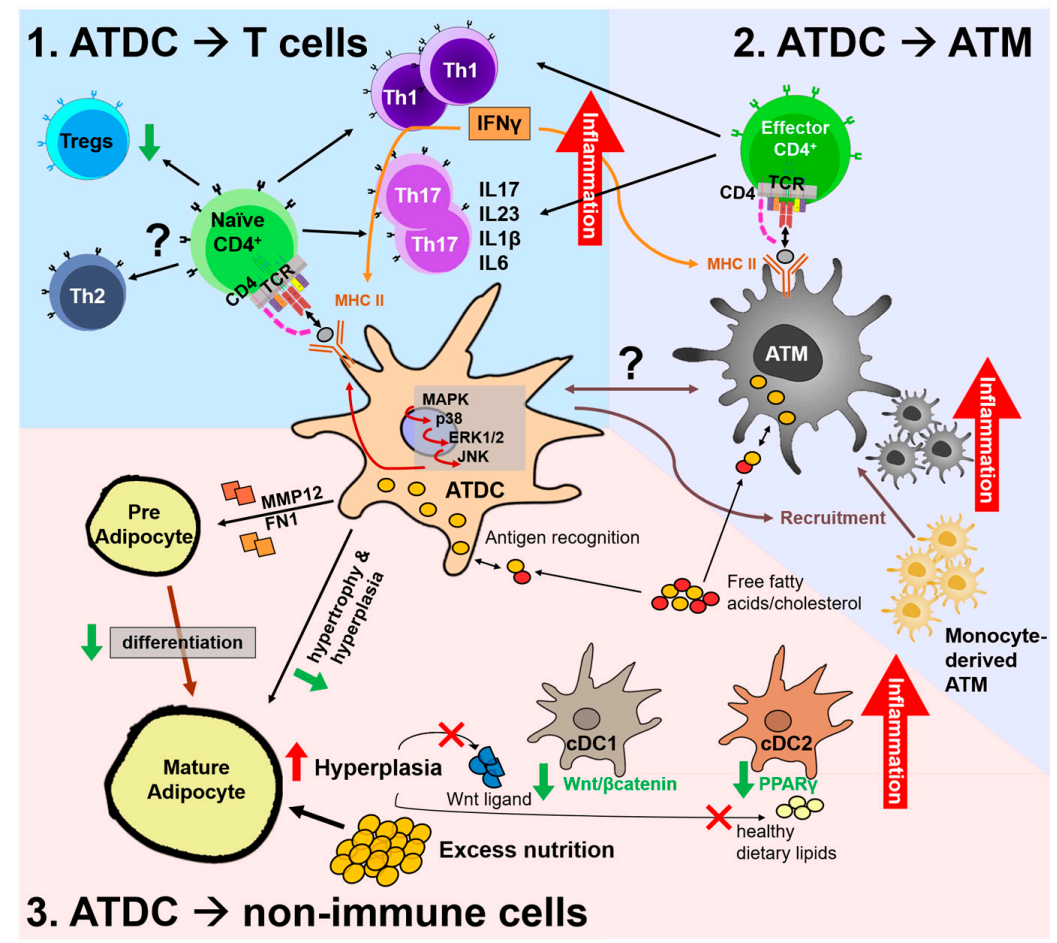

Figure 2. Potential regulatory mechanisms by adipose tissue dendritic cells (ATDCs) in the adipose tissue (AT) environment by interaction with T cells (1), AT macrophages (ATMs) (2), and non-immune cells (3). In obese AT, uptake of antigens or lipids such as free fatty acids and/or cholesterol by ATDCs induces activation of the mitogen-activated protein kinase (MAPK) pathway, leading to increased MHC-II expression and induced maturation. 1. Obese ATDCs lead the Th1 and Th17 subset proliferation that creates the pro-inflammatory environment. Released IFN $\gamma$ is capable of inducing MHC-II expression in antigen-presenting cells, creating a loop to amplify Th1 and exacerbate AT inflammation. In obesity, ATDCs have a lower capability to induce Tregs proliferation, while interaction with the Th2 subset is unknown. Separately, ATMs can uptake antigens inside the AT and induce proliferation of local effector $\mathrm{CD}^{+} \mathrm{T}$ cells into Th1 and/or Th17 subsets. 2. ATDCs partly regulate monocyte-derived ATM recruitment into AT, yet their interaction remains elusive. 3. Obese ATDCs fail to preserve their tolerogenic function in steady state to prevent preadipocyte differentiation and hyperplasia. Excess nutrition induces adipocyte hyperplasia, which decreases Wnt ligand and healthy dietary lipid secretion and leads to decreased Wnt/ $\beta$-catenin signaling in cDC1s and inactive PPAR $\gamma$ in cDC2s, triggering an inflammatory state.

The T helper 2 (Th2) and Treg subsets are usually found in lean conditions and have anti-inflammatory properties, such as CD11 ${ }^{-}$ATM activation [74,75]. In obesity, the percentage of Th2 and Treg is reduced as AT inflammation and insulin resistance progress, suggesting an important role of Th2 and Treg in AT homeostasis [72]. Ex vivo experiments revealed that obese ATDCs have lower ability to differentiate Treg [30,52]. Recently, it was reported that inactivation of Ctnnb1 or PPAR $\gamma$ in ATDCs reduces Treg proliferation [38]. These findings indicate that tolerogenic effects of ATDCs through Th2/Treg differentiation would be essential to maintain AT homeostasis.

Collectively, ATDCs interact with Th2/Treg in lean AT and potentially induce Th1 and Th17 proliferation in obesity. It remains unclear how ATDCs can play the tolerogenic or immunogenic functions depending on environmental cues or whether specific ATDC subsets have certain different functions.

\subsection{Regulator of Adipose Tissue Inflammation by Macrophage Infiltration}

Although ATDCs and ATMs share the same AP markers, their transcription profiles are unique, indicating that both are independent cells and they can crosstalk to each other 
in AT. The interaction between macrophages and DCs appears to be essential for the obesity-induced inflammation [12,31,48]. Stefanovic-Racic et al. found that $F l t 3 l^{-/-}$mice, which lack DCs, have lower ATM amounts, and the administration of DC or Flt3L promotes ATM infiltration [31]. Similarly, GM-CSF knockout mice showed lower ATM infiltration and accumulation under HFD, which contributes to amelioration of AT inflammation and insulin resistance [48]. In addition, a study used $\mathrm{Cr}^{-1} 7^{-/}$mice, where lack of ATDCs was observed during lean and obese and demonstrated failure of ATM accumulation under obesity [12]. These findings suggest that ATDCs might regulate ATM function and accumulation, especially in obesity. However, as has been mentioned previously, these findings could not explain whether the effect is truly regulated by DC or not since other cells were also affected. It is not clear yet whether ATDCs and ATMs interact directly or indirectly through cytokine release, and whether activated-ATDCs could activate ATMs, or vice versa, or if each has an independent unrelated activation pathway. In the future, it is worth exploring how and which cells, whether ATMs and/or ATDCs, induce inflammation and insulin resistance in obesity.

\subsection{Regulator of Adipose Tissue Homeostasis by Communication with Non-Immune Cells}

Recently, immunometabolism has emerged as a major mechanism to DC immune regulation. In the AT environment, higher concentrations of lipid metabolites such as free fatty acid and cholesterol would mediate the interaction between adipocytes and ATDC, and then regulate AT inflammation. Conventional DCs can uptake the fatty acids released by adipocytes and use them as major fuel through oxidative phosphorylation or incorporate them in the membrane. Free fatty acids uptake by ATDCs will form lipid droplets (LD), which have important immunogenic properties, with high levels of LD promoting DC activation and antigen cross-presentation [76]. Not only $\mathrm{CD}^{+} \mathrm{T}$ cell activation, but crosspresentation activity was also induced by DC containing high level of LD (high-DC), as shown by increased $\mathrm{CD}^{+} \mathrm{T}$ cell activity. While high-DCs showed an immunogenic effect, low-DCs showed a tolerogenic effect with an increase of Tregs, reduced adipogenesis, and reduced endoplasmic reticulum (ER) stress. Tolerance can be achieved by increasing the low-DC/high-DC ratio [77]. The role of LD in ATDCs and ATMs and the regulation of obesity-induced inflammation still remain to be elucidated.

Interaction between ATDCs and preadipocytes is another contributor in AT homeostasis, especially in adipocyte hypertrophy and hyperplasia $[47,78,79]$. Absence of ATDCs in $\mathrm{Csf2} 2^{-1-}$ mice have increased adipogenesis, adiposity, and larger adipocytes. Further, not GM-CSF, but a DC conditioned medium enriched with MMP12 and fibronectin proteins could prevent preadipocyte to adipocyte differentiation. This was confirmed by upregulation of Pref-1, marker of the preadipocyte state [80], and downregulation of adipogenesis

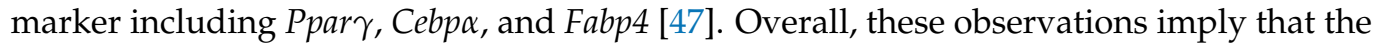
interaction between ATDCs and non-immune cells such as adipocytes and preadipocytes would be one of mechanism underlying the inflammation.

\section{Future Perspectives and Conclusions}

Accumulating evidence clearly demonstrates that ATDCs are central players in the development of AT inflammation by interacting with several different types of cell types in AT, thereby initiating and regulating obesity-induced inflammation and insulin resistance. Recent studies showed that the imbalance between the tolerogenic and pro-inflammatory function of ATDCs is mainly attributed to obesity-induced inflammation. It has been also found that increasing number of ATDCs in the obese state is accompanied by different functional properties, including higher AP marker, to induce $\mathrm{T}$ cell activation and secretion of pro-inflammatory cytokines. Despite the rapid advances in immunometabolism, understanding mechanisms of how ATDCs contribute to obesity-associated diseases has still become an important issue, and further studies are needed to obtain future clinical and therapeutic designs against obesity-associated diseases. Obvious questions that remains are as follows: (1) what might be the antigens that are driving inflammation, (2) what 
triggers activate ATDCs during obesity, and (3) what are the regulatory mechanisms of specific ATDC subsets.

Identification of the specific presented-antigen would give promising ways to prevent obesity-induced inflammation by blocking AP itself or inhibiting antigen processing. The importance of antigen-presentation in the adipose inflammation is clear from studies that adipose tissue $\mathrm{CD}^{+} \mathrm{T}$ cells have restricted $\mathrm{T}$ cell repertoires, and the diversity is more restricted in the obese adipose tissue [81]. In addition, it is noteworthy that obesity promoted the expression of antigen presentation molecules such as MHC-II, and costimulatory molecule expression in visceral fat and deficiency of MHC-II in APC improved glucose homeostasis in obese mice [12,57]. However, the nature of the relevant antigen(s) is still entirely unknown in obesity, while several possible self-antigens, such as DNA damage, hypoxia, cell toxicity, and saturated lipid/cholesterol, have been proposed [82]. Recent advances in $\mathrm{T}$ cell repertoire analysis as well as new techniques to identify antigens for $\mathrm{T}$ cell receptors may enable a successful search for antigens in obesity in a systematic way.

In peripheral tissues, resident DCs are activated directly by conserved pathogen molecules and indirectly by inflammatory mediators produced by other cell types that recognize such molecules. Interactions with $\mathrm{CD}^{+}$and $\mathrm{CD}^{+} \mathrm{T}$ cells can also induce DC activation. Although the activation of ATDCs in obesity is well known, it remains unelucidated why and how ATDCs become activated, and whether it would be due to other cell-derived factors or interaction with T cells. One study showed that HFD induced the gut microbiota-derived LPS alteration and increased the uptake of LPS to adipose tissue [83], indicating gut-microbiota derived pathogen might be a metabolic trigger to activate ATDCs during obesity. A recent study also demonstrated that modulating checkpoint co-inhibitory interactions have been successful in animal models of obesity-associated inflammation and metabolic dysfunctions [84], suggesting that interactions through co-stimulatory or co-inhibitory molecules would be another factor in the activation of ATDCs in obesity.

ATDCs are heterogenous populations with different subsets that can function as either tolerogenic or inflammatory actions [16]. Considering the diversity of ATDC subsets, comprehensive studies about interaction of specific ATDC subsets with other immune or non-immune cells would give greater knowledge. However, current studies about ATDCs in obesity have been limited due to the lack of animal models. One potential caveat of global DC-deficient models including $\mathrm{Flt}_{\mathrm{H}} \mathrm{I}^{-/-}, \mathrm{Csf} \mathrm{2}^{-/-}$, and $\mathrm{C} \mathrm{cr} 7^{-/-}$is the unavoidable defects to reflect the developmental and physiological consequences of DC deficiency in steady state. Another caveat of current animal models is lack of specificity of DC. Thus, a clear inducible model that could ablate ATDCs only during obesity progression is needed to elucidate specific ATDC actions. As a means to specifically deplete cDCs, a cDNA encoding human DTR was introduced into the $3^{\prime}$ untranslated region of the mouse Zbtb46 (also called zDC) gene. Unlike the previously characterized CD11c-DTR mice, non-cDCs such as pDCs, monocytes, macrophages, and NK cells were spared after DT administration [19]. The use of these systems will most certainly help clarify the role of cDCs in the initiation and development of obesity-associated AT inflammation and bring us a step closer to finding better therapeutic strategies. It is also needed to generate new animal models to investigate the function of specific DC subsets.

Based on the central role of ATDCs in the obesity-induced inflammation, ATDCs are now considered as the potential targets to modulate metabolic diseases. Targeting to all the DCs or even general molecules on ATDCs is inappropriate, since global depletion of DCs is very deleterious $[85,86]$. Rather, therapeutic interventions may target antigen or co-stimulatory/coinhibitory molecules, which are selectively acting under the proinflammatory state in obesity. Antigen-specific therapy may hold promise in the treatment of the metabolic syndrome. Future research should elucidate antigens during obesity and determine the best mechanism to target adaptive immunity to improve metabolic function in obesity. Further investigation and integration of these fields will be necessary to overcome obstacles and to open new approaches to improve the promising therapeutic option of ATDCs for the future. 
Author Contributions: S.S. and K.W.C. conceived the project and wrote the manuscript. All authors have read and agreed to the published version of the manuscript.

Funding: This research was funded by National Research Foundation of Korea, NRF-2014R1A1A1038426 and NRF-2019R1A2C1084684.

Institutional Review Board Statement: Not applicable.

Informed Consent Statement: Not applicable.

Data Availability Statement: Not applicable.

Conflicts of Interest: The authors declare no conflict of interest.

\section{Abbreviations}

\begin{tabular}{|c|c|}
\hline $\mathrm{AP}$ & Antigen Presentation \\
\hline APC & Antigen-Presenting Cell \\
\hline AT & Adipose Tissue \\
\hline ATDC & Adipose Tissue Dendritic Cell \\
\hline ATM & Adipose Tissue Macrophage \\
\hline BAT & Brown Adipose Tissue \\
\hline BATF & Basic Leucine Zipper ATF (Activating Transcription Factor)-like \\
\hline BMI & Body Mass Index \\
\hline CCL & C-motif Chemokine Ligand \\
\hline CCR & C-C Chemokine Receptor \\
\hline $\mathrm{CD}$ & Cluster of Differentiation \\
\hline $\mathrm{cDC}$ & Conventional DC \\
\hline CLEC & C-type Lectin Domain \\
\hline CLS & Crown Like Structures \\
\hline CLV & Collecting Lymphatic Vessel \\
\hline $\mathrm{DC}$ & Dendritic Cell \\
\hline DIO & Diet-induced Obesity \\
\hline DT & Diphtheria Toxin \\
\hline DTR & Diphtheria Toxin Receptor \\
\hline ER & Endoplasmic Reticulum \\
\hline FMS & Feline McDonough Sarcoma \\
\hline FLT3 & FMS-like Tyrosine Kinase \\
\hline FLT3L & FMS-like Tyrosine Kinase Ligand \\
\hline $\mathrm{FN}$ & Fibronectin \\
\hline GM-CSF & Granulocyte Macrophage Colony Stimulating Factor \\
\hline HFD & High Fat Diet \\
\hline HSPC & Hematopoietic Stem and Progenitor Cell \\
\hline IL & Interleukin \\
\hline IRF & Interferon Regulatory Factor \\
\hline ITGAX & Integrin Alpha X \\
\hline MAPK & Mitogen-Activated Protein Kinase \\
\hline MerTK & MER Proto-Oncogene, Tyrosine Kinase \\
\hline MHC & Major Histocompatibility Complex \\
\hline MMP & Matrix Metallopeptidase \\
\hline moDC & Monocyte-derived DC \\
\hline ND & Normal Diet \\
\hline $\mathrm{pDC}$ & Plasmacytoid DC \\
\hline SAT & Subcutaneous Adipose Tissue \\
\hline SLO & Secondary Lymphoid Organ \\
\hline TCR & T Cell Receptor \\
\hline TLR & Toll-like Receptor \\
\hline TREM & Triggering Receptor Expressed on Myeloid Cell \\
\hline $\mathrm{UCP}$ & Uncoupling Protein \\
\hline VAT & Visceral Adipose Tissue \\
\hline ZBTB & Zinc Finger and BTB (Broad-Complex, Tramtrack and Bric a Bra \\
\hline
\end{tabular}




\section{References}

1. Hotamisligil, G.S. Inflammation and metabolic disorders. Nature 2006, 444, 860-867. [CrossRef] [PubMed]

2. Choe, S.S.; Huh, J.Y.; Hwang, I.J.; Kim, J.I.; Kim, J.B. Adipose Tissue Remodeling: Its Role in Energy Metabolism and Metabolic Disorders. Front. Endocrinol. 2016, 7, 30. [CrossRef]

3. Liu, R.; Nikolajczyk, B.S. Tissue Immune Cells Fuel Obesity-Associated Inflammation in Adipose Tissue and Beyond. Front. Immunol. 2019, 10, 1587. [CrossRef]

4. Ivanov, S.; Merlin, J.; Lee, M.K.S.; Murphy, A.J.; Guinamard, R.R. Biology and function of adipose tissue macrophages, dendritic cells and B cells. Atherosclerosis 2018, 271, 102-110. [CrossRef]

5. Steinman, R.M.; Cohn, Z.A. Identification of a novel cell type in peripheral lymphoid organs of mice. I. Morphology, quantitation, tissue distribution. J. Exp. Med. 1973, 137, 1142-1162. [CrossRef] [PubMed]

6. Steinman, R.M.; Cohn, Z.A. Identification of a novel cell type in peripheral lymphoid organs of mice. II. Functional properties in vitro. J. Exp. Med. 1974, 139, 380-397. [CrossRef] [PubMed]

7. Steinman, R.M.; Lustig, D.S.; Cohn, Z.A. Identification of a novel cell type in peripheral lymphoid organs of mice. 3. Functional properties in vivo. J. Exp. Med. 1974, 139, 1431-1445. [CrossRef]

8. Hotamisligil, G.S.; Shargill, N.S.; Spiegelman, B.M. Adipose expression of tumor necrosis factor-alpha: Direct role in obesity-linked insulin resistance. Science 1993, 259, 87-91. [CrossRef] [PubMed]

9. Rask-Madsen, C.; Kahn, C.R. Tissue-Specific Insulin Signaling, Metabolic Syndrome, and Cardiovascular Disease. Arterioscler. Thromb. Vasc. Biol. 2012, 32, 2052-2059. [CrossRef]

10. Wang, Q.; Wu, H. T Cells in Adipose Tissue: Critical Players in Immunometabolism. Front. Immunol. 2018, 9, 2509. [CrossRef]

11. Lu, J.; Zhao, J.; Meng, H.; Zhang, X. Adipose Tissue-Resident Immune Cells in Obesity and Type 2 Diabetes. Front. Immunol. 2019, 10, 1173. [CrossRef]

12. Cho, K.W.; Zamarron, B.F.; Muir, L.A.; Singer, K.; Porsche, C.E.; DelProposto, J.B.; Geletka, L.; Meyer, K.A.; O’Rourke, R.W.; Lumeng, C.N. Adipose Tissue Dendritic Cells Are Independent Contributors to Obesity-Induced Inflammation and Insulin Resistance. J. Immunol. 2016, 197, 3650-3661. [CrossRef]

13. Miller, J.C.; Brown, B.D.; Shay, T.; Gautier, E.L.; Jojic, V.; Cohain, A.; Pandey, G.; Leboeuf, M.; Elpek, K.G.; Helft, J.; et al. Immunological Genome Consortium. Deciphering the transcriptional network of the dendritic cell lineage. Nat. Immunol. 2012, 13, 888-899. [CrossRef]

14. Schraml, B.U.; Reis e Sousa, C. Defining dendritic cells. Curr. Opin. Immunol. 2015, 32, 13-20. [CrossRef]

15. Fitzgerald-Bocarsly, P.; Dai, J.; Singh, S. Plasmacytoid dendritic cells and type I IFN: 50 years of convergent history. Cytokine Growth Factor Rev. 2008, 19, 3-19. [CrossRef]

16. Sato, K.; Fujita, S. Dendritic Cells-Nature and Classification. Allergol. Int. 2007, 56, 183-191. [CrossRef]

17. Martin, P.; del Hoyo, G.M.; Anjuère, F.; Arias, C.F.; Fernández Arias, C.; Hernandez-Vargas, H.; Fernaández-L, A.; Parrillas, V.; Ardavín, C. Characterization of a new subpopulation of mouse CD8 $\alpha+$ B220+ dendritic cells endowed with type 1 interferon production capacity and tolerogenic potential. Blood 2002, 100, 383-390. [CrossRef]

18. Banchereau, J.; Briere, F.; Caux, C.; Davoust, J.; Lebecque, S.; Liu, Y.-J.; Pulendran, B.; Palucka, K. Immunobiology of Dendritic Cells. Annu. Rev. Immunol. 2000, 18,767-811. [CrossRef]

19. Meredith, M.M.; Liu, K.; Darrasse-Jeze, G.; Kamphorst, A.O.; Schreiber, H.A.; Guermonprez, P.; Idoyaga, J.; Cheong, C.; Yao, K.-H.; Niec, R.; et al. Expression of the zinc finger transcription factor zDC (Zbtb46, Btbd4) defines the classical dendritic cell lineage. J. Exp. Med. 2012, 209, 1153-1165. [CrossRef]

20. Den Haan, J.M.; Lehar, S.M.; Bevan, M.J. Cd8 $8^{+}$but Not Cd8 $8^{-}$Dendritic Cells Cross-Prime Cytotoxic T Cells in Vivo. J. Exp. Med. 2000, 192, 1685-1696. [CrossRef]

21. Del Rio, M.-L.; Rodriguez-Barbosa, J.-I.; Kremmer, E.; Förster, R. CD103- and CD103+ bronchial lymph node dendritic cells are specialized in presenting and cross-presenting innocuous antigen to CD4+ and CD8+ T cells. J. Immunol. 2007, 178, 6861-6866. [CrossRef]

22. Bedoui, S.; Whitney, P.; Waithman, J.; Eidsmo, L.; Wakim, L.M.; Caminschi, I.; Allan, R.; Wojtasiak, M.; Shortman, K.; Carbone, F.R.; et al. Cross-presentation of viral and self antigens by skin-derived CD103+ dendritic cells. Nat. Immunol. 2009, 10, 488-495. [CrossRef]

23. Noubade, R.; Majri-Morrison, S.; Tarbell, K.V. Beyond cDC1: Emerging Roles of DC Crosstalk in Cancer Immunity. Front. Immunol. 2019, 10, 1014. [CrossRef]

24. Tussiwand, R.; Everts, B.; Grajales-Reyes, G.E.; Kretzer, N.M.; Iwata, A.; Bagaitkar, J.; Wu, X.; Wong, R.; Anderson, D.A.; Murphy, T.L.; et al. Klf4 Expression in Conventional Dendritic Cells Is Required for T Helper 2 Cell Responses. Immunity 2015, 42, 916-928. [CrossRef]

25. Shortman, K.; Liu, Y.-J. Mouse and human dendritic cell subtypes. Nat. Rev. Immunol. 2002, 2, 151-161. [CrossRef] [PubMed]

26. Collin, M.; McGovern, N.; Haniffa, M. Human dendritic cell subsets. Immunology 2013, 140, 22-30. [CrossRef] [PubMed]

27. Calabro, S.; Liu, D.; Gallman, A.; Nascimento, M.S.L.; Yu, Z.; Zhang, T.-T.; Chen, P.; Zhang, B.; Xu, L.; Gowthaman, U.; et al. Differential Intrasplenic Migration of Dendritic Cell Subsets Tailors Adaptive Immunity. Cell Rep. 2016, 16, 2472-2485. [CrossRef] [PubMed] 
28. Dudziak, D.; Kamphorst, A.O.; Heidkamp, G.F.; Buchholz, V.R.; Trumpfheller, C.; Yamazaki, S.; Cheong, C.; Liu, K.; Lee, H.-W.; Park, C.G.; et al. Differential Antigen Processing by Dendritic Cell Subsets in Vivo. Science 2007, 315, 107-111. [CrossRef] [PubMed]

29. Gao, Y.; Nish, S.A.; Jiang, R.; Hou, L.; Licona-Limón, P.; Weinstein, J.S.; Zhao, H.; Medzhitov, R. Control of T Helper 2 Responses by Transcription Factor IRF4-Dependent Dendritic Cells. Immunity 2013, 39, 722-732. [CrossRef]

30. Bertola, A.; Ciucci, T.; Rousseau, D.; Bourlier, V.; Duffaut, C.; Bonnafous, S.; Blin-Wakkach, C.; Anty, R.; Iannelli, A.; Gugenheim, J.; et al. Identification of Adipose Tissue Dendritic Cells Correlated with Obesity-Associated Insulin-Resistance and Inducing Th17 Responses in Mice and Patients. Diabetes 2012, 61, 2238-2247. [CrossRef] [PubMed]

31. Stefanovic-Racic, M.; Yang, X.; Turner, M.S.; Mantell, B.S.; Stolz, D.B.; Sumpter, T.L.; Sipula, I.J.; Dedousis, N.; Scott, D.K.; Morel, P.; et al. Dendritic Cells Promote Macrophage Infiltration and Comprise a Substantial Proportion of Obesity-Associated Increases in CD11c+ Cells in Adipose Tissue and Liver. Diabetes 2012, 61, 2330-2339. [CrossRef]

32. Fisher, P.J.; Bulur, P.A.; Vuk-Pavlovic, S.; Prendergast, F.G.; Dietz, A.B. Dendritic cell microvilli: A novel membrane structure associated with the multifocal synapse and T-cell clustering. Blood 2008, 112, 5037-5045. [CrossRef] [PubMed]

33. Porsche, C.E.; Delproposto, J.B.; Patrick, E.; Zamarron, B.F.; Lumeng, C.N. Adipose tissue dendritic cell signals are required to maintain T cell homeostasis and obesity-induced expansion. Mol. Cell. Endocrinol. 2020, 505, 110740. [CrossRef]

34. Lumeng, C.N.; Bodzin, J.L.; Saltiel, A.R. Obesity induces a phenotypic switch in adipose tissue macrophage polarization. J. Clin. Investig. 2007, 117, 175-184. [CrossRef] [PubMed]

35. Russo, L.; Lumeng, C.N. Properties and functions of adipose tissue macrophages in obesity. Immunology 2018, 155, 407-417. [CrossRef]

36. Ivanov, S.; Scallan, J.P.; Kim, K.-W.; Werth, K.; Johnson, M.W.; Saunders, B.T.; Wang, P.L.; Kuan, E.L.; Straub, A.C.; Ouhachi, M.; et al. CCR7 and IRF4-dependent dendritic cells regulate lymphatic collecting vessel permeability. J. Clin. Investig. 2016, 126, 1581-1591. [CrossRef] [PubMed]

37. Satpathy, A.T.; Kc, W.; Albring, J.C.; Edelson, B.T.; Kretzer, N.M.; Bhattacharya, D.; Murphy, T.L.; Murphy, K.M. Zbtb46 expression distinguishes classical dendritic cells and their committed progenitors from other immune lineages. J. Exp. Med. 2012, 209, 1135-1152. [CrossRef]

38. Macdougall, C.E.; Wood, E.G.; Loschko, J.; Scagliotti, V.; Cassidy, F.C.; Robinson, M.E.; Feldhahn, N.; Castellano, L.; Voisin, M.-B.; Marelli-Berg, F.; et al. Visceral Adipose Tissue Immune Homeostasis Is Regulated by the Crosstalk between Adipocytes and Dendritic Cell Subsets. Cell Metab. 2018, 27, 588.e4-601.e4. [CrossRef] [PubMed]

39. Rajan, S.S.; Longhi, M.P. Dendritic cells and adipose tissue. Immunology 2016, 149, 353-361. [CrossRef]

40. Muir, L.A.; Kiridena, S.; Griffin, C.; DelProposto, J.B.; Geletka, L.; Martinez-Santibañez, G.; Zamarron, B.F.; Lucas, H.; Singer, K.; Rourke, R.W.O.; et al. Frontline Science: Rapid adipose tissue expansion triggers unique proliferation and lipid accumulation profiles in adipose tissue macrophages. J. Leukoc. Biol. 2018, 103, 615-628. [CrossRef]

41. Silva, H.M.; Báfica, A.; Rodrigues-Luiz, G.F.; Chi, J.; Santos, P.D.A.; Reis, B.S.; van Konijnenburg, D.P.H.; Crane, A.; Arifa, R.D.N.; Martin, P.; et al. Vasculature-associated fat macrophages readily adapt to inflammatory and metabolic challenges. J. Exp. Med. 2019, 216, 786-806. [CrossRef]

42. Ferrante, A.W. The immune cells in adipose tissue. Diabetes Obes. Metab. 2013, 15, 34-38. [CrossRef] [PubMed]

43. Weinstock, A.; Brown, E.J.; Garabedian, M.L.; Pena, S.; Sharma, M.; Lafaille, J.; Moore, K.J.; Fisher, E.A. Single-Cell RNA Sequencing of Visceral Adipose Tissue Leukocytes Reveals that Caloric Restriction Following Obesity Promotes the Accumulation of a Distinct Macrophage Population with Features of Phagocytic Cells. Immunometabolism 2019, 1, e190008. [PubMed]

44. Morris, D.L.; Oatmen, K.E.; Mergian, T.A.; Cho, K.W.; DelProposto, J.L.; Singer, K.; Evans-Molina, C.; O’Rourke, R.W.; Lumeng, C.N. CD40 promotes MHC class II expression on adipose tissue macrophages and regulates adipose tissue CD4+ T cells with obesity. J. Leukoc. Biol. 2016, 99, 1107-1119. [CrossRef]

45. Alvarez, D.; Vollmann, E.H.; von Andrian, U.H. Mechanisms and Consequences of Dendritic Cell Migration. Immunity 2008, 29, 325-342. [CrossRef]

46. Waskow, C.; Liu, K.; Darrasse-Jeze, G.; Guermonprez, P.; Ginhoux, F.; Merad, M.; Shengelia, T.; Yao, K.; Nussenzweig, M.C. The receptor tyrosine kinase Flt3 is required for dendritic cell development in peripheral lymphoid tissues. Nat. Immunol. 2008, 9 , 676-683. [CrossRef] [PubMed]

47. Pamir, N.; Liu, N.-C.; Irwin, A.; Becker, L.; Peng, Y.; Ronsein, G.E.; Bornfeldt, K.E.; Duffield, J.S.; Heinecke, J.W. Granulocyte/Macrophage Colony-stimulating Factor-dependent Dendritic Cells Restrain Lean Adipose Tissue Expansion. J. Biol. Chem. 2015, 290, 14656-14667. [CrossRef]

48. Kim, D.-H.; Sandoval, D.; Reed, J.A.; Matter, E.K.; Tolod, E.G.; Woods, S.C.; Seeley, R.J. The role of GM-CSF in adipose tissue inflammation. Am. J. Physiol. Metab. 2008, 295, E1038-E1046. [CrossRef]

49. Plubell, D.L.; Fenton, A.M.; Wilmarth, P.A.; Bergstrom, P.; Zhao, Y.; Minnier, J.; Heinecke, J.W.; Yang, X.; Pamir, N. GM-CSF driven myeloid cells in adipose tissue link weight gain and insulin resistance via formation of 2-aminoadipate. Sci. Rep. 2018, 8, 11485. [CrossRef]

50. Sano, T.; Sanada, T.; Sotomaru, Y.; Shinjo, T.; Iwashita, M.; Yamashita, A.; Fukuda, T.; Sanui, T.; Asano, T.; Kanematsu, T.; et al. Ccr7 null mice are protected against diet-induced obesity via Ucp1 upregulation and enhanced energy expenditure. Nutr. Metab. 2019, 16, 1-9. [CrossRef] [PubMed] 
51. McKenna, H.J.; Stocking, K.L.; Miller, R.E.; Brasel, K.; De Smedt, T.; Maraskovsky, E.; Maliszewski, C.R.; Lynch, D.H.; Smith, J.; Pulendran, B.; et al. Mice lacking flt3 ligand have deficient hematopoiesis affecting hematopoietic progenitor cells, dendritic cells, and natural killer cells. Blood 2000, 95, 3489-3497. [CrossRef]

52. Chen, Y.; Tian, J.; Tian, X.; Tang, X.; Rui, K.; Tong, J.; Lu, L.; Xu, H.; Wang, S. Adipose Tissue Dendritic Cells Enhances Inflammation by Prompting the Generation of Th17 Cells. PLoS ONE 2014, 9, e92450. [CrossRef] [PubMed]

53. Jung, S.; Unutmaz, D.; Wong, P.; Sano, G.-I.; Santos, K.D.L.; Sparwasser, T.; Wu, S.; Vuthoori, S.; Ko, K.; Zavala, F.; et al. In Vivo Depletion of CD11c+ Dendritic Cells Abrogates Priming of CD8+ T Cells by Exogenous Cell-Associated Antigens. Immunity 2002, 17, 211-220. [CrossRef]

54. Patsouris, D.; Li, P.-P.; Thapar, D.; Chapman, J.; Olefsky, J.M.; Neels, J.G. Ablation of CD11c-Positive Cells Normalizes Insulin Sensitivity in Obese Insulin Resistant Animals. Cell Metab. 2008, 8, 301-309. [CrossRef]

55. Zangi, L.; Klionsky, Y.Z.; Yarimi, L.; Bachar-Lustig, E.; Eidelstein, Y.; Shezen, E.; Hagin, D.; Ito, Y.; Takai, T.; Reich-Zeliger, S.; et al. Deletion of cognate CD8 T cells by immature dendritic cells: A novel role for perforin, granzyme A, TREM-1, and TLR. Blood 2012, 120, 1647-1657. [CrossRef]

56. Zlotnikov-Klionsky, Y.; Nathansohn-Levi, B.; Shezen, E.; Rosen, C.; Kagan, S.; Bar-On, L.; Jung, S.; Shifrut, E.; Reich-Zeliger, S.; Friedman, N.; et al. Perforin-Positive Dendritic Cells Exhibit an Immuno-regulatory Role in Metabolic Syndrome and Autoimmunity. Immunity 2015, 43, 776-787. [CrossRef] [PubMed]

57. Cho, K.W.; Morris, D.L.; DelProposto, J.L.; Geletka, L.; Zamarron, B.; Martinez-Santibanez, G.; Meyer, K.A.; Singer, K.; O’Rourke, R.; Lumeng, C.N. An MHC II-Dependent Activation Loop between Adipose Tissue Macrophages and CD4+ T Cells Controls Obesity-Induced Inflammation. Cell Rep. 2014, 9, 605-617. [CrossRef]

58. Deng, T.; Lyon, C.J.; Minze, L.J.; Lin, J.; Zou, J.; Liu, J.Z.; Ren, Y.; Yin, Z.; Hamilton, D.; Reardon, P.R.; et al. Class II Major Histocompatibility Complex Plays an Essential Role in Obesity-Induced Adipose Inflammation. Cell Metab. 2013, 17, 411-422. [CrossRef]

59. Zhang, H.; Zhang, S.-Y.; Jiang, C.; Li, Y.; Xu, G.; Xu, M.-J.; Wang, X. Intermedin/adrenomedullin 2 polypeptide promotes adipose tissue browning and reduces high-fat diet-induced obesity and insulin resistance in mice. Int. J. Obes. 2016, 40, 852-860. [CrossRef] [PubMed]

60. Zhang, S.-Y.; Lv, Y.; Zhang, H.; Gao, S.; Wang, T.; Feng, J.; Wang, Y.; Liu, G.; Xu, M.-J.; Wang, X.; et al. Adrenomedullin 2 Improves Early Obesity-Induced Adipose Insulin Resistance by Inhibiting the Class II MHC in Adipocytes. Diabetes 2016, 65, 2342-2355. [CrossRef]

61. Poggi, M.; Engel, D.; Christ, A.; Beckers, L.; Wijnands, E.; Boon, L.; Driessen, A.; Cleutjens, J.; Weber, C.; Gerdes, N.; et al. CD40L Deficiency Ameliorates Adipose Tissue Inflammation and Metabolic Manifestations of Obesity in Mice. Arter. Thromb. Vasc. Biol. 2011, 31, 2251-2260. [CrossRef]

62. Zhong, J.; Rao, X.; Braunstein, Z.; Taylor, A.; Narula, V.; Hazey, J.; Mikami, D.; Needleman, B.; Rutsky, J.; Sun, Q.; et al. T-Cell Costimulation Protects Obesity-Induced Adipose Inflammation and Insulin Resistance. Diabetes 2014, 63, 1289-1302. [CrossRef]

63. Wu, H.; Ghosh, S.; Perrard, X.D.; Feng, L.; Garcia, G.E.; Perrard, J.L.; Sweeney, J.F.; Peterson, L.; Chan, L.; Smith, C.W.; et al. T-Cell Accumulation and Regulated on Activation, Normal T Cell Expressed and Secreted Upregulation in Adipose Tissue in Obesity. Circulation 2007, 115, 1029-1038. [CrossRef]

64. Nishimura, S.; Manabe, I.; Nagasaki, M.; Eto, K.; Yamashita, H.; Ohsugi, M.; Otsu, M.; Hara, K.; Ueki, K.; Sugiura, S.; et al. CD8+ effector T cells contribute to macrophage recruitment and adipose tissue inflammation in obesity. Nat. Med. 2009, 15, 914-920. [CrossRef]

65. Kintscher, U.; Hartge, M.; Hess, K.; Foryst-Ludwig, A.; Clemenz, M.; Wabitsch, M.; Fischer-Posovszky, P.; Barth, T.F.E.; Dragun, D.; Skurk, T.; et al. T-lymphocyte Infiltration in Visceral Adipose Tissue: A Primary Event in Adipose Tissue Inflammation and the Development of Obesity-Mediated Insulin Resistance. Arterioscler. Thromb. Vasc. Biol. 2008, 28, 1304-1310. [CrossRef]

66. Tai, Y.; Wang, Q.; Korner, H.; Zhang, L.; Wei, W. Molecular Mechanisms of T Cells Activation by Dendritic Cells in Autoimmune Diseases. Front. Pharmacol. 2018, 9, 642. [CrossRef]

67. Khan, I.M.; Dai Perrard, X.-Y.; Perrard, J.L.; Mansoori, A.; Smith, C.W.; Wu, H.; Ballantyne, C.M. Attenuated adipose tissue and skeletal muscle inflammation in obese mice with combined CD4+ and CD8+ T cell deficiency. Atherosclerosis 2014, 233, 419-428. [CrossRef]

68. Morris, D.; Cho, K.W.; DelProposto, J.L.; Oatmen, K.E.; Geletka, L.M.; Martinez-Santibanez, G.; Singer, K.; Lumeng, C.N. Adipose Tissue Macrophages Function as Antigen-Presenting Cells and Regulate Adipose Tissue CD4 + T Cells in Mice. Diabetes 2013, 62, 2762-2772. [CrossRef] [PubMed]

69. Khan, I.M.; Perrard, X.-Y.; Brunner, G.; Lui, H.; Sparks, L.M.; Smith, S.R.; Wang, X.; Shi, Z.-Z.; Lewis, D.E.; Wu, H.; et al. Intermuscular and perimuscular fat expansion in obesity correlates with skeletal muscle $\mathrm{T}$ cell and macrophage infiltration and insulin resistance. Int. J. Obes. 2015, 39, 1607-1618. [CrossRef] [PubMed]

70. Rocha, V.Z.; Folco, E.J.; Sukhova, G.; Shimizu, K.; Gotsman, I.; Vernon, A.H.; Libby, P. Interferon- $\gamma$, a Th1 Cytokine, Regulates Fat Inflammation: A Role for Adaptive Immunity in Obesity. Circ. Res. 2008, 103, 467-476. [CrossRef] [PubMed]

71. Fabbrini, E.; Cella, M.; Mccartney, S.A.; Fuchs, A.; Abumrad, N.A.; Pietka, T.A.; Chen, Z.; Finck, B.N.; Han, D.H.; Magkos, F.; et al. Association Between Specific Adipose Tissue CD4+ T-Cell Populations and Insulin Resistance in Obese Individuals. Gastroenterology 2013, 145, 366.e3-374.e3. [CrossRef] [PubMed] 
72. McLaughlin, T.; Liu, L.-F.; Lamendola, C.; Shen, L.; Morton, J.; Rivas, H.; Winer, D.; Tolentino, L.; Choi, O.; Zhang, H.; et al. T-Cell Profile in Adipose Tissue Is Associated with Insulin Resistance and Systemic Inflammation in Humans. Arter. Thromb. Vasc. Biol. 2014, 34, 2637-2643. [CrossRef] [PubMed]

73. Chehimi, M.; Vidal, H.; Eljaafari, A. Pathogenic Role of IL-17-Producing Immune Cells in Obesity, and Related Inflammatory Diseases. J. Clin. Med. 2017, 6, 68. [CrossRef] [PubMed]

74. Molofsky, A.; Nussbaum, J.C.; Liang, H.-E.; Van Dyken, S.J.; Cheng, L.E.; Mohapatra, A.; Chawla, A.; Locksley, R.M. Innate lymphoid type 2 cells sustain visceral adipose tissue eosinophils and alternatively activated macrophages. J. Exp. Med. 2013, 210, 535-549. [CrossRef]

75. Wu, D.; Molofsky, A.B.; Liang, H.-E.; Ricardo-Gonzalez, R.; Jouihan, H.A.; Bando, J.; Chawla, A.; Locksley, R.M. Eosinophils Sustain Adipose Alternatively Activated Macrophages Associated with Glucose Homeostasis. Science 2011, 332, $243-247$. [CrossRef]

76. Den Brok, M.H.; Raaijmakers, T.K.; Collado-Camps, E.; Adema, G.J. Lipid Droplets as Immune Modulators in Myeloid Cells. Trends Immunol. 2018, 39, 380-392. [CrossRef]

77. Ibrahim, J.; Nguyen, A.H.; Rehman, A.; Ochi, A.; Jamal, M.; Graffeo, C.S.; Henning, J.R.; Zambirinis, C.; Fallon, N.C.; Barilla, R.; et al. Dendritic Cell Populations with Different Concentrations of Lipid Regulate Tolerance and Immunity in Mouse and Human Liver. Gastroenterology 2012, 143, 1061-1072. [CrossRef]

78. Tran, K.-V.; Gealekman, O.; Frontini, A.; Zingaretti, M.C.; Morroni, M.; Giordano, A.; Smorlesi, A.; Perugini, J.; De Matteis, R.; Sbarbati, A.; et al. The Vascular Endothelium of the Adipose Tissue Gives Rise to Both White and Brown Fat Cells. Cell Metab. 2012, 15, 222-229. [CrossRef]

79. Hong, K.Y.; Bae, H.; Park, I.; Park, D.-Y.; Kim, K.H.; Kubota, Y.; Cho, E.-S.; Kim, H.; Adams, R.H.; Yoo, O.-J.; et al. Perilipin ${ }^{+}$ embryonic preadipocytes actively proliferate along growing vasculatures for adipose expansion. Development 2015, 142, 2623-2632. [CrossRef]

80. Hudak, C.S.; Sul, H.S. Pref-1, a Gatekeeper of Adipogenesis. Front. Endocrinol. 2013, 4, 79. [CrossRef] [PubMed]

81. Yang, H.; Youm, Y.-H.; Vandanmagsar, B.; Ravussin, A.; Gimble, J.M.; Greenway, F.; Stephens, J.M.; Mynatt, R.L.; Dixit, V.D. Obesity Increases the Production of Proinflammatory Mediators from Adipose Tissue T Cells and Compromises TCR Repertoire Diversity: Implications for Systemic Inflammation and Insulin Resistance. J. Immunol. 2010, 185, 1836-1845. [CrossRef]

82. Chng, M.H.Y.; Alonso, M.N.; Barnes, S.E.; Nguyen, K.D.; Engleman, E.G. Adaptive Immunity and Antigen-Specific Activation in Obesity-Associated Insulin Resistance. Mediat. Inflamm. 2015, 2015, 1-15. [CrossRef]

83. Hersoug, L.; Møller, P.; Loft, S. Gut microbiota-derived lipopolysaccharide uptake and trafficking to adipose tissue: Implications for inflammation and obesity. Obes. Rev. 2016, 17, 297-312. [CrossRef] [PubMed]

84. Berg, S.M.V.D.; Seijkens, T.; Kusters, P.J.H.; Zarzycka, B.; Beckers, L.; den Toom, M.; Gijbels, M.J.J.; Chatzigeorgiou, A.; Weber, C.; De Winther, M.P.J.; et al. Blocking CD40-TRAF6 interactions by small-molecule inhibitor 6860766 ameliorates the complications of diet-induced obesity in mice. Int. J. Obes. 2014, 39, 782-790. [CrossRef] [PubMed]

85. Birnberg, T.; Bar-On, L.; Sapoznikov, A.; Caton, M.L.; Cervantes-Barragán, L.; Makia, D.; Krauthgamer, R.; Brenner, O.; Ludewig, B.; Brockschnieder, D.; et al. Lack of Conventional Dendritic Cells Is Compatible with Normal Development and T Cell Homeostasis, but Causes Myeloid Proliferative Syndrome. Immunity 2008, 29, 986-997. [CrossRef] [PubMed]

86. Jiao, J.; Dragomir, A.-C.; Kocabayoglu, P.; Rahman, A.H.; Chow, A.; Hashimoto, D.; Leboeuf, M.; Kraus, T.; Moran, T.; CarrascoAvino, G.; et al. Central Role of Conventional Dendritic Cells in Regulation of Bone Marrow Release and Survival of Neutrophils. J. Immunol. 2014, 192, 3374-3382. [CrossRef] 